\title{
THE IMPORTANCE OF TRANSACTION COSTS IN AGRICULTURE - A REVIEW OF SELECTED EMPIRICAL STUDIES
}

\author{
A IMPORTÂNCIA DOS CUSTOS DE TRANSAÇÃO NA \\ AGRICULTURA - UMA REVISÃO DE ESTUDOS EMPÍRICOS \\ SELECIONADOS
}

\author{
Alcido Elenor Wander ${ }^{1}$
}

\begin{abstract}
In this literature review we illustrate the application of Transaction Cost Economics (TCE) to agribusiness based on four empirical studies on assessing transaction costs (TC) in different countries. Main findings are: (a) the lack of empirical studies on TC at farm level; (b) no standard procedure to assess TC; and (c) TC can be much more important than it has been believed by economists. In fact, what is needed is not just one more study revising what main sources related to TC said in a theoretical way. We need more empirical studies, where authors really assess what is going on at the transaction level. That information will provide more valuable information for public and private decision makers.
\end{abstract}

keywords: New institutional economics; Transaction cost economics; Agriculture; Governance structures; Agribusiness.

\section{RESUMO}

Nesta revisão bibliográfica, ilustrou-se a utilização da economia dos custos de transação no agronegócio, com base em quatro estudos empíricos que avaliaram custos de transação em diferentes países. Principais resultados: (a) escassez de estudos empíricos no que diz respeito a fazendas; (b) ausência de procedimentos-padrão para avaliar custos de transação; (c) os custos de transação podem ser bem mais expressivos do que vinham sendo considerados pelos economistas. Na realidade, não são necessários mais estudos que apenas revisam teoricamente os principais autores, o que é imprescindível são mais estudos empíricos, nos quais os autores realmente avaliam o que ocorre em relação à transação. Esses conhecimentos proporcionarão informações importantes para os tomadores de decisão públicos e privados.

Palavras-chave: Nova economia institucional; Economia dos custos de transação; Agricultura; Estruturas de governança; Agronegócio.

\section{Introduction}

A transaction is defined by Williamson (1985) as the transfer of a good or service through a separable interface. One phase ends and a new phase will start. A consequence of Williamson's definition is that it is limited to situations where resources are physically

\footnotetext{
${ }^{1}$ Graduado em Agronomia pela Universidade de Kassel (1996), mestre em Ciências Agrárias dos Trópicos e Subtrópicos - Georg-August-Universität Göttingen (1998) e doutor em Ciências Agrárias - Georg-AugustUniversität Göttingen (2002). Atualmente é professor titular da Faculdade Alfa, pesquisador da Universidade Federal de Goiás e da Empresa Brasileira de Pesquisa Agropecuária.
} 
transferred. Those physical transfers may occur within the firms as well as between firms, using markets. Thus, there are internal transactions within the firm and market transactions, which can be understood as a result of labour division (RICHTER \& FURUBOTN, 1999, p. 47).

Commons (1934, p. 58) defines transaction as the transfer of the property right on a good or service, which does not consider only the physical transfer, but also the transfer in terms of property and rights of using a resource, which leads to the contracts related to the use of resources.

Since both transactions types, physically and of property rights, are economic transactions, their costs attracted the attention of scientists in several countries (RICHTER \& FURUBOTN, 1999, p. 48). The transaction represents the heart of analysis (COMMONS, 1934). Transaction, especially nature-related transactions are typical for agriculture, horticulture, fishery and forestry which interact frequently with natural systems (HAGEDORN, 2008).

The theoretical model of transaction costs (TC) has its origin in different areas of economic research, mainly in new institutional economics and firm theory (WILLIAMSON, 1998). It is based on the seminal work of Coase (1937), showing that the coordination of economic transactions through markets are not free, and generate transaction costs. The neoclassic theory already considered uncertainty, but neglected asset specificity and frequency. Altogether, those aspects have a systematic influence on economic behaviour (RICHTER \& FURUBOTN, 1999).

The theory of transaction costs deals with the problem of economic organization from a microanalytic perspective (COASE, 1937). The focus of the theory is on the transactions and the saving attempts in the organization of transactions. After Williamson (1985, p. 19) we know that the economic institutions of capitalism mainly look for reduction of transaction costs. Additionally, Williamson (1996) argues that the contract man differs from the orthodox view of benefit maximizer in two ways: first, the condition of bounded rationality and second, the contract man act on his own interest in a much stronger and disturbing way than the benefit maximizer (WILLIAMSON, 1996, p. 6), which can be seen as opportunism. The transaction cost economics links bounded rationality with opportunism.

In firm theory transaction costs are understood as the sacrifice required to overcome information problems (PICOT, 1981). There are authors like Eggertsson (1995) that separate transaction costs from information costs. These information problems are related to economic relations, e.g. search, comparison, trust, control and uncertainty about effects of environmental changes. Their importance can vary according to the situation. The application of the concept is not restricted to economic relations, but can be adapted to social and political components.

At macroeconomic level, Arrow $(1969$, p. 48) defines transaction costs as the running costs of an economic system. Richter \& Furubotn (1999) emphasize that also the costs of setup, maintenance and adaptation of the rules of a system need to be considered. Therefore, Richter \& Furubotn (1999, p. 49) define transaction costs at macroeconomic level as the cost of setup, use, maintenance and adaptation of institutions on the basis of objective laws, e.g. the constitution of a country, and institutions on the basis of subjective laws, e.g. a legal right born from a voluntary agreed working contract.

Transaction costs may be divided into: 
- Market transaction costs: cost of using markets for transactions;

- Firm transaction costs: costs of exercising the right of giving orders within the firm;

- Political transaction costs: costs of use and adaptation of formal institutions.

Following the neoclassical economic thinking, the transaction can be included in a function, like the production in the production function. Richter \& Furubotn (1999) show a transaction function similarly to a production function, using a case were a farmer produces wheat to sell to a consumer (= the transaction). In this example of Richter \& Furubotn (1999), the transaction function is $Y_{c}=F\left(Y_{p}\right)$. The index $p$ represents the amount of wheat the farmer agreed to supply and the index $c$ the amount of wheat the consumer agreed to demand.

Graphically the transaction function can be represented as in Figure 1. The curve format refers to an ordinary production function. The $O A$ segment represents the amount offered by the supplier (= transaction input), i.e., the amount of wheat the farmers supplies in our example. The $O B$ segment represents the amount of goods or services received by the demander (= transaction output), i.e. the amount of wheat received by the consumer in our example.

The $C D$ segment represents the transaction costs calculated as $K=Y_{p}-Y_{c}$. From Figure 1 we can observe that in situations of positive transaction costs $(\mathrm{TC}>0)$ the transaction curve must be located below the $45^{\circ}$ line.

The climb gradient of the transaction cost curve can be seen as the marginal productivity of the transaction (RICHTER \& FURUBOTN, 1999). It shows how many units of service the demander receives for each additional unit provided by the supplier. As shown in Figure 1, the marginal productivity of the transaction declines by increasing the frequency. This is due to the assumption of increasing marginal transaction costs by increasing quantities. This assumption becomes effective if after a certain quantity the demander has to look for additional suppliers and the transactions require additional control efforts. The costs of control and enforcement rise since with increasing quantities the parties take more care on opportunistic behaviour of transaction partners. 
Figure 1 - The transaction function

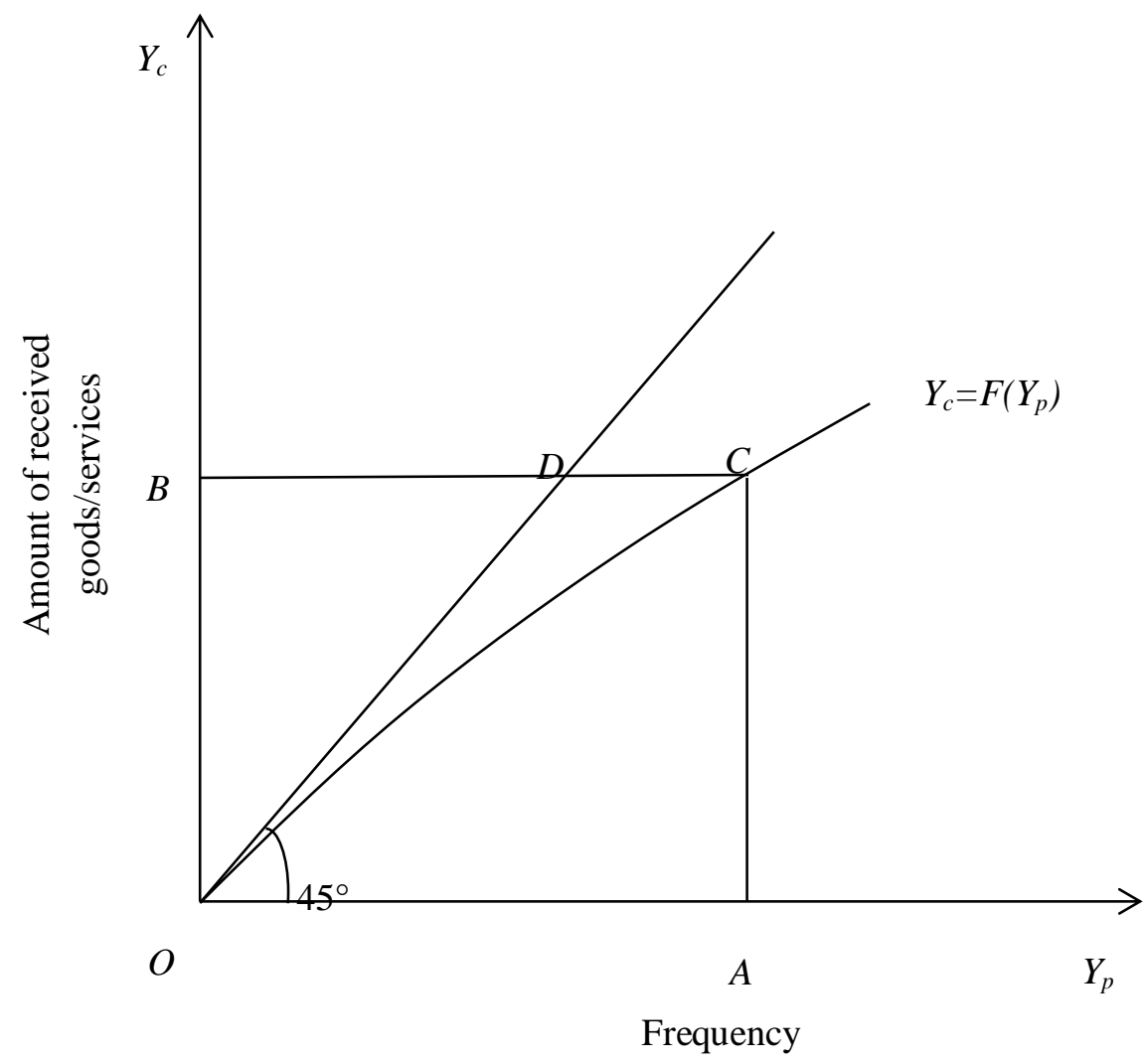

Source: Adapted from RICHTER \& FURUBOTN (1999).

From Shelanski \& Klein (1995) we learned that TCE analyses how transaction partners protect themselves against dangers that may result from a transaction. The transaction partners choose institutional alternatives that may result in lower transaction cost, in order to protect their transaction specific assets.

After Picot (1981), the transaction costs can be divided in accordance with the phase of transaction (Table 1). This classification allows a better understanding and facilitates the empirical implementation of the transaction cost model. Other classifications are possible, but they will not be further explored in this paper.

Table 1 - Transaction costs in dependence of the phase of the transaction

\begin{tabular}{|l|l|}
\hline \multicolumn{1}{|c|}{ Transaction cost } & \multicolumn{1}{c|}{ Where they occur } \\
\hline 1) Costs of information & $\begin{array}{l}\text { Search and acquisition of information about potential transaction } \\
\text { partners and their conditions. }\end{array}$ \\
\hline 2) Costs of negotiation & $\begin{array}{l}\text { Intensity and time consumption of negotiations, contract } \\
\text { formulation and reach an agreement. }\end{array}$ \\
\hline $\begin{array}{l}\text { 3) Costs of control and } \\
\text { monitoring }\end{array}$ & $\begin{array}{l}\text { Ensuring of compliance of agreed dates, quality, quantity, price } \\
\text { and eventually confidentiality. }\end{array}$ \\
\hline 4) Costs of adaptation & $\begin{array}{l}\text { Enforcement of changes in dates, quality, quantity and price due } \\
\text { to changing conditions during the agreement period. }\end{array}$ \\
\hline
\end{tabular}

Source: Own compilation after Picot (1981), Richter \& Furubotn (1999). 
According to Heidhues et al. (1997) both transacting parties experience transaction costs. They include fix (setup) and variable (running) transaction costs. Information is crucial in all phases of the transaction.

To assess transaction costs other indicators than monetary units can be added, since there may be a long-term factor use that may not be quantifiable in monetary units (PICOT, 1981; WILLIAMSON, 1998). In many cases, nominal and ordinal comparisons save costly exact measurements of single transaction costs. According to Williamson (1998), the main importance is not to have exact figures on the transaction costs, but to compare the different costs resulting from different decisions. Even being a simplification, often ranking lists are enough to show, how important the transaction costs are.

The transaction costs can also be divided into fixed and variable transaction costs. Fixed transaction costs are the setup costs of an institution that enables an alternative contractual choice to be offered. The variable transaction costs represent all expenditures occurring while using an existent short or long-term contractual choice for hiring any services.

Williamson (1985) focused on the question: Under which conditions are transactions organized within "hierarchies" - that is within firms - and not in markets as conventional neo-classical economics suggests. Williamson (1985) also considers "hybrid forms" or organization such as alliances between different firms (hierarchies). The different types of organizations are also referred to as governance structures.

To empirically apply the transaction cost approach it is fundamental to know the main attributes of transactions. Williamson $(1985,1998)$ defines uncertainty, frequency and asset specificity as the attributes of transactions. Shelanski \& Klein (1995) add complexity as a fourth attribute of transactions. Alchian \& Demsetz (1972) and Barzel (1982) also consider the measurability as an important attribute of transactions. In order to capture the peculiarities of transactions, in a study on machinery services Wander et al. (2003) considered other attributes like the requirement of group activities and specific hold-up possibilities.

Thus, the main objective of the present paper is to introduce the main theoretical ideas behind the transaction cost economics and illustrate its application on agribusiness with examples of empirical studies trying to assess transaction costs experienced by farmers in different countries.

\section{Development}

The present work is essentially a literature review on selected transaction costs and empiric studies related to different segments of agribusiness, in different countries. It is neither the intention to present all available studies, nor can the selected studies be considered as the most significant ones. They are just a selection of cases, without any ranking or quality assessment, to cover study and country diversity.

Empirical studies on transaction costs exist for some areas, but there are only few trying to estimate transaction costs. Most studies recognize the existence and importance of transaction costs, but only a few try to measure them. Important contributions to measuring transaction costs were done by Crocker \& Masten (1996), Lyons (1996) and Shelanski \& Klein (1995). The limited number of empirical studies on transaction costs is justified by the difficulty in measurement. Picot (1981) goes further, saying that it is very hard to value 
transaction costs, particularly ex-ante, e.g. cost for seeking, contract formulation and control. However, they are real and of significant economic importance (EGGERTSSON, 1995; PICOT, 1981).

Zylbersztajn (2005) discusses the relevance of the contract approach to the theory of the firm, presents the evolution of the studies of coordination in food chains in Brazil and abroad, and concludes a research and educational agenda for applied agricultural economics.

Regarding its type, the empiric studies available in worldwide literature on transaction costs can be classified into (a) qualitative case studies, (b) quantitative case studies and (c) cross sectional and panel regressions. The focus of those studies can be, from micro to macro, at contract level, at governance level and at institutional level (ALTMAN et al., 2007). Considering the condition and goods or services involved in the transaction, farmers can be supplier and demander of goods and services. We shortly discuss four studies:

- Farmer supplying goods: Bánkuti et al. (2008);

- Farmer supplying services: Van Kooten et al. (2002);

- Farmer demanding goods: Badstue et al. (2006); and

- Farmer demanding services: Wander \& Zeller (2002), Wander et al. (2003).

\subsection{Study 1 - Assessment of transaction costs of dairy farms at formal and informal markets in São Carlos region, São Paulo state}

This study aimed to present an analysis and a measurement of the transaction costs for two groups of dairy farms in the region of São Carlos, São Paulo state and it is documented by Bánkuti et al. (2008).

The authors measured the transaction costs of dairy farms in accessing formal and informal markets to commercialize their production. Some farmers accessed mainly informal markets, others focused more on formal markets.

Both formal and informal markets had low negotiation costs (transaction costs). Operational production costs represented $97 \%$ of total production costs for formal markets. For those farmers accessing informal markets, the operational production costs represented $88 \%$, followed by transport related costs of $11 \%$.

The main reasons why transaction costs are low in this study are related to the fact that since milk is a perishable product, farmers will avoid any kind of conflict. Contract breaches were not common, also because of passive behaviour of farmers.

From the sample of dairy farms considered, the authors concluded that transaction costs are low for all considered farms. However, those farms that access mainly informal markets had relatively higher transaction costs than farmers accessing formal markets.

The authors also observed that only a few contracts are available, which is related to the high frequency of transaction for marketing dairy production and the resulting establishment of reliability among transaction partners. 


\subsection{Study 2 - Transaction costs of planting trees to mitigate climate change in Canada}

This study aimed to examine and present economic aspects of the institutions and incentives needed to encourage landowner in Canada to adopt tree planting on a large scale and it is documented by Van Kooten et al. (2002).

Worldwide land use change and forestry projects are considered a low-cost option for addressing climate change mitigation. According to Van Kooten et al. (2002), in Canada, afforestation is targeted to sequester enough carbon to meet one-fifth of its international obligations, and at lower cost than emissions reduction.

According to the authors, farmers are reluctant in make dramatic changes in the way they use their land. High transaction costs related to incomplete contracting can be a major barrier to contracting in tree planting, since there is a great deal of uncertainty. Catastrophic fires, wind blow downs, large change in values of $\mathrm{C}$ offset, lack of certification, among other unforeseen circumstances raise truncation costs of farmers going into tree planting, according to the study.

There are also evidences that asset specificity in form of developed land and investments in tractors, combines, and other assets specific to crop production may be an obstacle to afforestation. Finally, the farmers would not be willing to enter into tree-planting agreements that exceed about 15 years. Native trees would take about 40 years to reach the expected growth.

In the study of Van Kooten et al. (2002), the transaction costs of getting landowners to convert their land from agriculture to plantation forests appear to be a significant obstacle, possibly increasing the costs of afforestation projects beyond what conventional economic analysis suggests.

\subsection{Study 3 - Transaction costs of collective action to access maize seeds in Central Valleys of Oaxaca, Mexico}

This study aimed to explore social arrangements associated with seed transactions among small-scale maize farmers in the Central Valleys of Oaxaca, Mexico, where no formal supply system exists. It is documented by Badstue et al. (2006).

According to the authors, research in the Central Valleys also indicated that farmers who needed to acquire seed from other farmers experienced some difficulty in finding seed that met their requirements. First, a farmer has to learn who grows which maize variety and investigate the characteristics and performance of the maize of interest. Then he or she must make sure that the information offered is trustworthy and the seed is reliable. Finally, the conditions of acquiring the seed must be negotiated. It therefore appears that acquiring seed of diverse maize varieties under these conditions can entail risks and high transaction costs to individual farmers.

Farmers mostly saved seed and only occasionally acquired seed from outside sources. The authors found no evidence of a specialized social organization based on collective action to mediate seed flows. Seed transactions were infrequent, bilateral, and ad hoc, although trust was an important component, as it ensured reliable information about the seed was provided.

In the study, the authors identified several different types of seed transactions:

1) Purchase: Seed that has been bought and paid for in cash. It represented more than $52 \%$ of all transactions in the study. 
2) Inheritance: When parents or foster parents pass on maize seed to their children or foster children. This can be when the parents die, or when the children become independent of their parents and start to farm on their own.

3) Exchange Seed of one kind of maize is exchanged for the same quantity of seed of another kind of maize. Sometimes seed is acquired in exchange for grain, but then quantities normally vary, as seed has higher value than grain.

4) Gift: In this transaction seed is provided without payment, whether monetary or in kind.

5) Barter: This is an exchange in kind, i.e., maize seed is given for some other good of use to the seed provider (e.g., beans or coffee).

6) Borrowed: The seed provider hands over the seed to the person requesting it, while the latter in turn promises to give back the same quantity of seed of the same kind of maize once it has been harvested.

7) Other: This category contains various other ways of obtaining seed: sharecropping, pepena (gleaning), seed won in a lottery, payment realized in kind with maize, and seed acquired without the knowledge of the seed provider.

The main seed providers identified by the authors were family members. However, also other providers, like compadres, neighbours, friends, Acquaintances, Strangers and others were mentioned as seed providers.

The authors identified the lack of records as one of the main difficulties in assessing the frequency of seed transactions. Social relations are of high importance in the selection of seed provider.

\subsection{Study 4: Transaction costs of obtaining agricultural machinery services at farm level in Southern Brazil}

This study and its main outcomes are documented in Wander \& Zeller (2002) and Wander et al. (2003).

The mechanization of agricultural production plays an important and in course of time increasing role in the course of agricultural and rural development. Mechanization offers a number of potential improvements to farming systems such as increased land and labour productivity, reduction of risks, and increase of quality and food safety of animal and plant products. However, investments in own machinery, in particular for smallholders, may not be the least-cost option in comparison with outsourcing the required machinery services through different contractual relationships. In order to choose the optimal contract for obtaining machinery services, it is necessary to evaluate conventional machinery costs as well as transaction costs.

The main objective of the study was to assess the role of transaction costs in the choice among alternative contractual arrangements for provision of machinery services.

Some authors have argued earlier that it is useful to consider - next to markets and hierarchies - co-operative forms as a third, distinct, governance structure (BIRNER \& WITTMER, 2000). Co-operative forms include both formal registered co-operatives and a wide variety of more informal organizations. Co-operative types of organization, such as 
marketing, processing and credit co-operatives, play an important role in the agricultural sector, especially in developing countries. The above case study confirms that general observation is also true for the case of machinery. For analytical purposes, the authors considered co-operative forms next to markets and hierarchies as a distinct type of organization, because these co-operative organizations are by definition non-hierarchical and have to overcome the problems of collective action that are quite different from the principleagent problem typically found in hierarchical relations. In the agricultural sector, the state often also plays a role as provider of services and has, therefore, to be considered as a further distinct type of organization. Considering markets, hierarchies, co-operatives and state agencies as four basic types of organization, the contractual arrangements found in our Brazilian case study can be classified as followed:

1) Market arrangements: A market transaction occurs, e.g. if a farmer hires a machine from a provider without establishing any relationship with the provider. In a typical agricultural setting, this pure "spot market" for machinery services does not appear to be very relevant, because the farmers may continuously hire machinery from the same provider, thus establishing a relationship. Between the available contractual arrangements farmer contractors represent the most market-oriented solution. But even here some relationships between provider and asking farmer can be found. In some cases the farmers prefer to re-use the same farmer contractor because of the established relationship. This leads to the following type of governance structure.

2) Hierarchical arrangements: If a farmer purchases the machine for his farm, one can interpret this as a "hierarchical arrangement" in Williamson's sense because the transaction is organized within the farm enterprise (hierarchy) rather than hired in form of a market transaction. If a farmer establishes a long-term relational contract with an enterprise to hire in machinery services, this has can also be considered as a hierarchical arrangement.

3) Co-operative arrangements: The case study shows that it is useful to consider three different types of co-operative arrangements: a) Informal sharing: Sharing of machinery and work between neighbours without cash payment. The payment could be in kind or even in work. This type of organization occurs mainly on farms with smaller area; b) Farmer groups: Informal group of farmers, who buy machinery together and use it within the group (often extended family members and their neighbours); c) Cooperatives: Formal organized larger group of farms, where farmers are members and pay annual fees and the machinery belongs to the cooperative.

4) Contractual arrangements with state agencies: If, for instance, local governments own the machines and provide services to farmers against monetary payment.

Transaction cost theory (WILLIAMSON, 1985) suggests that assets with relatively high initial investment costs, and high specificity, will likely be sourced through contract services rather than through asset ownership. In a study on multi-farm mechanization in Southern Brazil, we identified as specific and expensive technologies mainly harvesting machinery (combines, which are very expensive, and one-row tractor mounted silage harvesters, which are very specific as they only can be used for the corn silage harvest). In the mentioned study, it was shown that the transaction costs can be higher than conventional machinery costs, and therefore, they are important cost elements in the decision-making process concerning the choice of contract for outsourcing harvesting technology for silage corn or own investment (WANDER \& ZELLER, 2002). Especially the losses due to delays in beginning the harvest as well as the risk of hold-up effects and the need of group activities 
(machines and labour) lead farmers to prefer self-help arrangements such as farmer groups and, sometimes, co-operatives to provide the needed services with silage harvesters.

\section{Concluding remarks}

After giving an overview of some empiric studies on transaction costs at farm level in different countries, some remarks have to be made. First, there is a need for more empirical studies on transaction costs at farm level. Most of the empirical studies on transaction costs focus on the perspective of the industry. Farmers' perspective has been neglected so far.

Second, there is no standard procedure to assess transaction costs. In each situation, the specific transactions have to be described and modelled in order to enable a sound way of assessing them.

And finally, transaction costs can be much more important than it has been believed by economists. In fact, what is needed is not just one more study revising what main sources related to transaction costs said in a theoretical way. We need more empirical studies, where authors really assess what is going on at the transaction level. That information will provide more valuable information for public and private decision makers.

\section{REFERENCES}

ALCHIAN, A. A.; DEMSETZ, H. Production, information costs, and economic organization. In: WILLIAMSON, O. E.; MASTEN, S. E. The economics of transaction costs. Cheltenham, UK and Northampton, MA: Elgar Critical Writings Reader, 1999, p. 35-53.

ALTMAN, I. J.; KLEIN, P. G.; JOHNSON, T. G. Scale and transaction costs in the U.S. Biopower industry. Journal of Agricultural \& Food Industrial Organization, v. 5 (Article 10), 2007.

ARROW, K. J. The organization of economic activity: issues pertinent to the choice of market versus non-market allocation. In: CONGRESS OF JOINT ECONOMIC COMMITTEE, $91^{\text {st }}$, Washington, D.C. The analysis and evaluation of public expenditures: the PBB-system, $1^{\text {st }}$ session, v. 1, 1969.

BADSTUE, L. B.; BELLON, M. R.; BERTHAUD, J.; JUÁREZ, X.; ROSAS, I. M.; SOLANO, A. M.; RAMÍREZ, A. Examining the role of collective action in an informal seed system: a case study from the Central Valleys of Oaxaca, Mexico. Human Ecology, v. 34, n. 2, p. 249-273, 2006.

BÁNKUTI, F. I.; SOUZA FILHO, H. M. D.; BÁNKUTI, S. M. S. Mensuração e análise de custos de transação arcados por produtores de leite nos mercados formal e informal da região de São Carlos, SP. Organizações Rurais \& Agroindustriais, v. 10, n. 3, p. 343-358, 2008.

BARZEL, Y. Measurement cost and the organization of markets. Journal of Law \& Economics, v. 25, p. 27-78, 1982.

BIRNER, R.; WITTMER, H. Co-management of natural resources: a transaction costs economics approach to determine the efficient boundaries of the state. In: ANNUAL 
IINTERNATIONAL CONFERENCE OF THE INTERNATIONAL SOCIETY OF THE NEW INSTITUTIONAL ECONOMICS, Tübingen, 2000.

COASE, R. H. The nature of the firm. Economica, v. 4, n. 16, p. 386-405, 1937.

COMMONS, W. Institutional economics: it's place in political economy. New York: Macmillan, 1934.

CROCKER, K. J.; MASTEN S. Regulation and administered contracts revisited: lessons from transaction-cost economics for public utility regulation. Journal of Regulatory Economics, v. 9, n. 1, p. 5-39, 1996.

EGGERTSSON, T. Economic behavior and institutions. New York: Cambridge University Press, 1995.

HAGEDORN, K. Particular requirements of institutional analysis in nature-related sectors. European Review of Agricultural Economics, v. 35, n. 3, p. 357-384, 2008.

HEIDHUES, F.; BELLE-SOSSOH, D.; SCHRIEDER, G. Transaction costs of group and individual lending and rural financing market access: the case of poverty oriented microfinance in Cameroon. In: INTERNATIONAL CONFERENCE OF IAAE, 23th, 1997, Sacramento, USA.

LYONS, B. R. Contracts and specific investment: an empirical test of transaction cost theory. Journal of Economics \& Management Strategy, v. 3, n. 2, p. 257-278, 1994.

PICOT, A. Transaktionskostentheorie der Organisation. Hannover: Lehrgebiet für BWL, Universität Hannover, 1981.

RICHTER, R.; FURUBOTN, E. G. Neue institutionenökonomik: eine einführung und kritische würdigung. 2 ed. Tübingen: Mohr Siebeck, 1999.

SHELANSKI, H. A.; KLEIN, P. G. Empirical research in transaction cost economics: a review and assessment. The Journal of Law, Economics \& Organization, v. 11, n. 2, p. 335-361, 1995.

VAN KOOTEN, G. C.; SHAIKH, S. L.; SUCHÁNEK, P. Mitigating climate change by planting trees: the transaction costs trap. Land Economics, v. 78, n. 4, p. 559-572, 2002.

WANDER, A. E.; BIRNER, R.; WITTMER, H. Can transaction cost economics explain the different contractual arrangements for the provision of agricultural machinery services? A case study of brazilian state of Rio Grande do Sul. Brazilian Journal of Theoretical and Applied Economics, v.1, n. 20, p. 9-26, 2003.

WANDER, A. E.; ZELLER, M. Contractual arrangements and transaction costs: the case of small-holder mechanization in Southern Brazil. Quarterly Journal of International Agriculture, v. 41, n. 4, p. 317-334, 2002.

WILLIAMSON, O. E. The economic institutions of capitalism: firms, markets and relational contracting. New York: The Free Press, 1985.

Transaction cost economics: how it works, where it is headed. The Economist, v. 146, n. 1, p. 23-58, 1998.

Transaktionskostenökonomik. 2. ed. Ökonomische Theorie der Institutionen, v. 3. Hamburg: Lit, 1996. 
ZYLBERSZTAJN, D. Papel dos contratos na coordenação agroindustrial: um olhar além dos mercados. Revista de Economia e Sociologia Rural, v. 43, n. 3, p. 385-420, 2005. 